\title{
Miranda
}

Revue pluridisciplinaire du monde anglophone /

Multidisciplinary peer-reviewed journal on the English-

speaking world

$17 \mid 2018$

Paysages et héritages de David Bowie

\section{Rachael Z. DeLue (ed.), Picturing}

\section{Marie-Odile Salati}

\section{OpenEdition}

\section{Journals}

Electronic version

URL: http://journals.openedition.org/miranda/15174

DOI: 10.4000/miranda.15174

ISSN: 2108-6559

\section{Publisher}

Université Toulouse - Jean Jaurès

\section{Electronic reference}

Marie-Odile Salati, "Rachael Z. DeLue (ed.), Picturing", Miranda [Online], 17 | 2018, Online since 02

October 2018, connection on 16 February 2021. URL: http://journals.openedition.org/miranda/15174 ; DOI: https://doi.org/10.4000/miranda.15174

\section{This text was automatically generated on 16 February 2021.}

\section{(9) $\odot \Theta$}

Miranda is licensed under a Creative Commons Attribution-NonCommercial-NoDerivatives 4.0 International License. 


\title{
Rachael Z. DeLue (ed.), Picturing
}

\author{
Marie-Odile Salati
}

\section{REFERENCES}

Rachael Z. DeLue (ed.), Picturing. vol. 1 of Terra Foundation Essays (Chicago, Paris: University of Chicago Press, 2016), 216 p., ISBN 978-0-932171-57-3

1 Picturing is the first issue of a planned series of six volumes published by Terra Foundation for American Art. The book consists of five essays plus an introduction by editor Rachael DeLue, which is an essay in itself laying the conceptual and methodological framework of the undertaking, most authors being academics specializing in American art history. The text, impeccably edited, is lavishly illustrated with a variety of high quality visual documents, which are the objects of fascinating thorough analyses. The only minor reservation about the material form of the book itself would be the type of print selected for chapter headings, which, related as it is to the central issue, is barely legible.

2 In her introduction, Rachael Z. DeLue begins with a perceptive analysis of an 1882 sketch by Winslow Homer in relation to some of his sea paintings in order to highlight his concern with impossible point of view, thus vindicating the relevance of the issue tackled by the volume, namely picture addressed as a series of operations implementing an idea and picturing as a construction of the visual. The aim is to enquire into the conditions of production of visual representation from the twofold standpoint of the individual artist and of the period and, by focusing on a number of significant instances, to provide a theoretical foundation for future research pertaining to the history and theory of visual representation in America. DeLue then proceeds to describe the methodological framework of the study, coming up with a useful elucidation of the key operative notions of picture, image, visual expression, backed by an extensive list of bibliographical references in the endnotes. She explains in what way Picturing is indebted to and articulates two major areas of ground-breaking research, specifying the respective ends of each, namely German Bildwissenschaft 
(notably the work of art historian Aby Warburg and the scholarly production of Horst Bredekamp) and visual culture as understood in the English-speaking world. The study, then, will be extended beyond the realm of the fine arts to include that of reproduction and media technologies and will be concerned with the social construction of images. The point is not the image per se but how it is seen as well as thought about, that is, the operation and historicity of picturing, as aptly suggested by the gerund form chosen for the title of the book. Consequently the research purposes intersect with the field of material culture, as it is defined by Jules Prown in his 1982 article and has developed in recent works dealing with all manner of artefacts, a large number of which are listed for reference in an endnote.

3 Since Picturing is the first issue of a six-volume series, Rachael DeLue expounds on the main objectives of the collection, particularly its ambition to contribute new interpretations in the field of American art history and to benefit from the insights of a transnational and transdisciplinary critical perspective. Challenging the notion that art is intricately linked with nation, the authors wish to bring out the concepts that are of particular significance in American art history owing to the country's historical, political, economic and cultural specificities, in an attempt to steer a middle course between exceptionalism and generality. After introducing each of the five essays in the book and stressing in what way they contribute to the exploration of the concept of picturing at different periods of time across a variety of representational mediums and disciplines as understood above, DeLue concludes by analyzing another of Winslow Homer's sketches, which she interprets as "a picture of picturing" mirroring the painter's persistent concern with "the nature and limits of pictures and picturing", thus affording a perfect illustration and vindication of the volume's purpose.

The first essay by Matthew C. Hunter ("Did Joshua Reynolds Paint His Pictures? The Transatlantic Work of Picturing in an Age of Chemycal Reproduction") reconsiders pictorial ontology in the light of the $18^{\text {th }}$ century model "pictor"'s technique, that is his deliberate reliance on the chemical transformation of his oil paintings and his splitting of picture from painted object. Hunter highlights Reynolds's concern with the material thingness of picture far ahead of the modernist tradition, as the artist had to take into account the deterioration of the pigments necessary to achieve the finest colouring and consequently depended on the assistance of engravers to ensure the posterity of his production. Being open to the technological innovations of his time, the painter welcomed the use of lithography, pollaplasiasmos and enamel reproduction, thus turning his paintings into pictures and blurring the borderline with photography. Considering Reynolds's influence in Britain as President of the Royal Academy and on $19^{\text {th }}$ century colonial American painters since numerous replicas of his works crossed the Atlantic, his enlistment of the chemical arts sheds new light on the reproductive strategies of the Anglo-American art of the time. It also calls for a reexamination of current assumptions about the period, for instance the primacy of the painter's intention, which Hunter suggests is played down by non-human factors like chance and time, and about art history, since photography thus proves to be just one instance of working with chemical transformation, not the culmination of an evolution. Not only does Hunter make his points meticulously and cogently, step by step, backing his arguments with a variety of primary sources from Reynolds's time, but he also includes considerable background information related to the development of the liberal and the chemical arts, and of industrial technology in the $18^{\text {th }}$ and $19^{\text {th }}$ centuries, supplying an 
impressive list of mostly recent bibliographical references for the reader's further enlightenment.

In the second essay entitled "Magical Pictures; or, Observations on Lightning and Thunder, Occasion'd by a Portrait of Dr. Franklin", Michael Gaudio, weaving together electrical experimentation and artistic representation, proposes to view Mason Chamberlin's famous 1762 portrait of Benjamin Franklin from another perspective than the commonly accepted one in art history and to learn to look beyond the picture at the thunderstorm outside the window. Taking electricity as a metaphorical conductor applied to the circulation of meaning, he suggests that the vivid painting aptly conveys the scientist's personal dilemma between confident faith in rational explanation and persisting wonder in the mysteries of divine nature, since the alternating current of meaning counteracts the usual interpretation going from outside natural chaos to human control through knowledge inside, with the opposite outgoing movement from the small-scale experiment of the electrician to the natural wonders which the scientist attempts to reproduce just as the painter aims at imitating nature. Gaudio then draws on Aby Warburg's investigation into the magical thinking evidenced in primitive Indian rain dances, which the likes of Franklin's electrical experiments contributed to routing. Drawing a parallel with Max Weber's theory of early $20^{\text {th }}$ century disenchantment with capitalism, the author points out the dual play of enchantment and disenchantment conveyed by Chamberlin's painting, which suggests the scientist's persistent sense of magic, in spite of his being a disenchanter of the modern world. It would have been interesting to complement this fascinating transdisciplinary exploration of the notion of wonder, indebted to James Delbourgo's work on Electricity and Enlightenment in Early America, with a brief foray into literature, addressing Tony Tanner's argument in The Reign of Wonder that wonder is a preeminently American attitude, and giving more emphasis to passing mentions of the sublime and of Charles Brockden Brown, the initiator of American Gothic, in order to tackle the boundary between rationality and the irrational forces beyond the picture.

6 Working along the line of Robin Kelsey's suggestion to inquire into the material conditions of photography, Elizabeth W. Hutchinson in "Conjuring in Fog: Eadweard Muybridge at Point Reyes", relies on thing theory to refute the prevailing view of the photographer's picturesque use of fog in his 1871 work on the northern California coast. She proposes instead to see fog as the index of man's negotiation with an inhospitable environment, an interpretation which in turn undermines the dominant "triumphant narrative of American expansion" by emphasizing the interference of nonhuman factors. To that end, she goes through a thorough investigation into the United States Coast Survey activities, the archives of the Lighthouse Board and explores various ethnological and environmental sources in order to retrace the historical development of man's difficult relationship with the Pacific coast, which is reflected in the so far overlooked meaningful presence of fog in Muybridge's pictures. Thus, the photographer's act of picturing has more to do with the visual culture of navigation than with the romantic landscape painting tradition. Hutchinson supplies invaluable information, that enriches our knowledge of man's relations with natural environment in the US, and she draws attention to the significant role played by paintings and photographs in that construction. She especially conducts an insightful comparative study of the American and Chinese approaches to point out the American quest for 
control but at times her search for documentation is so meticulous that the central issue of visual representation tends to recede from sight.

7 In the fourth essay ("Learning from Cézanne: Stein's Working with and through Picturing"), Ulla Haselstein shows how Gertrude Stein elaborated her art by transposing Paul Cézanne's visual strategies to her literary medium while at the same time moving beyond them into modernism owing to the additional resources of that very medium, which thus proved superior in her eyes. The author conducts a comparative analysis of the techniques of the two artists as they were understood by the writer, first examining the latter's implementation of the former's aesthetic principles in her work, then carrying out a close reading of a passage from Stein's portrait of Cézanne in her 1933-1934 lecture entitled "Pictures". The priestess of modernism relied on repetition to achieve a similar form of "egalitarian composition" ascribing as much importance to each part of the representation as to the whole and she played with the materiality of language through word-pattern, rhythm and tonal emphasis to emulate the painter's striking process of "réalisation", aimed at conveying the intense presence of the object under observation. What came as a revelation to her during her 1903-1904 encounter with Cézanne's innovative style was the artist's purpose to present the cognitive processes rather than the results of perception and his capacity to make picturing visible, that is the act of imagination necessary to reach an understanding of the whole picture, an operation which she found akin to reading a text. An examination of Stein's own attempt at picturing in her written portrait of Cézanne points out the limit of picturing in literature as she does not come up with a portrait of the painter but instead forcefully stages her own subjective response to his landscapes thanks to the aural resources of speech. Haselstein's brilliant micro-analysis of an obscure text may at times strike one as an illustration of the reader's act of imagination involved in the cognitive process since some instances of decoding need a leap of faith and would require firmer grounding. The lengthy account could profitably have been shortened to make way for a comparative analysis of Stein's portrait of Cézanne with the painter's portrait of his wife, owned by the poet and the source of the aesthetic reflections discussed in the essay.

8 Robin Kelsey's essay, "Pictorialism as Theory", concludes the volume with a most fitting theoretical reflection on the notion of picture conducted in the form of a historical survey of the shifting as well as uneasy uses of the term. Pointing out overlooked implications in Alberti's conception of "pictura" and in Diderot's handling of the French equivalent "tableau", namely the invisibility ascribed to the viewer, Kelsey argues that photography transformed the concept by breaking the traditional asymmetry between viewer and viewed object. Owing to the generalization of the medium, it was potentially restoring visibility to all, and consequently the formerly suppressed vulnerability of the subject to the look of others. To make his point, the author examines the social function which the daguerreotype carried for former black slave Frederick Douglass, as "a site of negotiation between self and society", and the abolitionist's belief in the power of picture to rouse empathy, a conception which prefigured the psychoanalytical reintegration of the subject into the picture. Viewed in the light of Lacan's theory of the gaze and of Sartre's definition of the Other, photography created the condition of "looked-at-ness" and was instrumental in the modern understanding of subjectivity. Like Frederick Douglass, Alfred Stieglitz was aware of displacement, which the concept of picture came to be inseparable from, but in a parallel analysis of the 1907 photogravure The Steerage and of the photographer's 
later written comments on his picturing of that work, Kelsey debunks the flaunted selfcomplacent image of alienation to highlight the return of the threatening gaze of the Other. To conclude, the critic briefly points out the relevance of his study to the "postpictorialist" phase of photography and to Jeff Wall's questionable understanding of "picture" in this light; also to cinematic issues with Cindy Sherman's film stills and to performance art as illustrated by Yvonne Rainier; finally to the institutionalization of "looked-at-ness" in modern-day surveillance. Kelsey thus provides a highly stimulating perspective and useful theoretical framework for tackling the concept of picture across the arts, in a remarkably clear accessible demonstration.

This first volume entirely meets its initial objectives and allows us to expect a most promising collection offering challenging new perspectives in the field of art history besides supplying a mine of bibliographical references. The traditional intermedial word-image approach is greatly enriched by large-scale contextualization and by crossings with other disciplines, notably technological and scientific ones. The work should be hailed for its documentation from unusual sources unrelated to art history, such as chemistry, electrical experimentation or coast survey activities. Another outstanding achievement of the book lies in its meticulous, compelling demonstrations, which leave no stone unturned. However, fascinating as they are, the essays occasionally tend to drift from the central aesthetic subject, launching into what may appear as lengthy digressions and discussions of historical niceties unrelated to artistic issues. It would seem advisable to maintain a harmonious balance between historical contextualization and art conceptualization.

\section{INDEX}

Keywords: art history, American art, visual arts, picture, painting, engraving, photography, literature, visual representation, intermediality, transdisciplinary criticism

Mots-clés: histoire de l'art, art américain, arts visuels, image, peinture, gravure, photographie, littérature, représentation visuelle, intermédialité, transdisciplinarité

\section{AUTHORS}

\section{MARIE-ODILE SALATI}

Professeur

Université Savoie Mont Blanc

marie-odile.salati@univ-smb.fr 